\title{
ИССЛЕДОВАНИЕ АДСОРБЦИИ ЦИКЛИЧЕСКИХ УГЛЕВОДОРОДОВ НА ГРАФИТИРОВАННОЙ ТЕРМИЧЕСКОЙ САЖЕ
}

В статье ['] рассмотрены закономерности изменения $-\overrightarrow{\Delta U}_{1}$ (дифференциальных мольных изменений внутренней энергии адсорбата) в зависимости от молекулярной структуры $H$-алканов, $H$-алкенов и $H$-алкинов $\mathrm{C}_{6}-\mathrm{C}_{10}$ на графитированной термической саже (ГТС). В настоящей работе приводятся аналогичные данные для монозамещенных алкилциклопентанов, -пентенов, -гексанов и -гексенов $\mathrm{C}_{6}-\mathrm{C}_{11}$.

Необходимые значения $-\overrightarrow{\Delta U}_{1}$ для $H$-алканов рассчитаны по уравнению $-\overrightarrow{\Delta U}_{1}=10,63+4,98 n \kappa Д ж /$ моль (табл. 2 [']). На основе полученных результатов с помощью уравнения (3) ['] вычисленные величины $-\overline{\Delta U}_{1}$ для циклических углеводородов сведены в табл. 1. Данные табл. 1 показывают, что существует линейная зависимость между значениями $-\overline{\Delta U}_{1}$ и числом атомов углерода в молекуле, которая описывается уравнением

$$
-\overline{\Delta U}_{1}=a_{0}+a_{1} n \text {. }
$$

Значения констант $a_{0}$ и $a_{1}$ рассчитаны методом наименьших квадратов (табл. 2).

При равном числе атомов углерода в молекуле для $\mathrm{H}$-алкилциклопентанов и -пентенов характерны более высокие значения индексов удерживания $(I)$, изостерических теплот адсорбции $\left(q_{s t, 1}\right)$ и $-\overline{\Delta U}_{1}$ по сравнению с соответствующими соединениями с шестичленными циклами.

Разветвление боковой цепи приводит к понижению значений $I, q_{s t, 1}$ и $-\overline{\Delta U}_{1}$ го сравнению с соответствующими углеводородами с нормальной алкильной группой у цикла. Это объясняется уменьшением числа контактирующих центров между углеводородом и ГТС при разветвлении заместителя. Так, изобутилциклогексан и изобутилциклогексен обладают более низкими значениями $q_{s t, 1}$ и $-\overrightarrow{\Delta U}_{1}$, чем $н$-бутилзамещенные производные этих углеводородов.

Значения $I, q_{s t, 1}$ и $-\overline{\Delta U}_{1}$ изученных циклопентенов и циклогексенов зависят от длины и положения заместителя. По мере удаления боковой цепи от кратной связи циклопентенового цикла - из положения 1 в положение 3 - значения $I$ для метил-, этил- и пропилциклопентенов уменьшаются, для бутил-, пентил- и гексилциклопентенов увеличиваются, а значения $q_{s t, 1}$ и $-\overline{\Delta U}_{1}$ уменьшаются для всех гомологов.

В группе изомерных $\boldsymbol{H}$-алкилциклогексенов при равном числе атомов 
Дифференциальные мольные изменения внутренней энергии адсорбции $\left(-\overrightarrow{\Delta U}_{1}\right)$ для алкилциклоалканов и алкилциклоалкенов $\mathrm{C}_{6}-\mathrm{C}_{11}$ на ГТС при малом заполнении поверхности, кДж/моль *

\begin{tabular}{|c|c|c|c|c|c|c|c|c|}
\hline \multirow{3}{*}{ Название адсорбата } & \multicolumn{7}{|c|}{$-\overline{\Delta U}_{1}, \kappa Д \nsim с / \mu о л b$} & \multirow{3}{*}{ 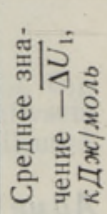 } \\
\hline & \multicolumn{7}{|c|}{ Температура, ${ }^{\circ} \mathrm{C}$} & \\
\hline & $\begin{array}{c}100 \text { и } \\
125\end{array}$ & $\begin{array}{c}125 \text { и } \\
150\end{array}$ & $\begin{array}{c}150 \text { и } \\
175\end{array}$ & $\begin{array}{c}175 \text { и } \\
200\end{array}$ & $\begin{array}{c}200 \text { и } \\
225\end{array}$ & $\begin{array}{c}225 \text { и } \\
250\end{array}$ & $\begin{array}{c}250 \text { и } \\
275\end{array}$ & \\
\hline 1 & 2 & 3 & 4 & 5 & 6 & 7 & 8 & 9 \\
\hline
\end{tabular}

Метилциклопентан Этилциклопентан н-Пропилциклопентан н-Бутилциклопентан н-Пентилциклопентан н-Гексилциклопентан

\section{Метилциклогексан} Этилциклогексан н-Пропилциклогексан Изопропилциклогексан н-Бутилциклогексан Изобутилциклогексан Втор. бутилциклогексан н-Гексилциклогексан

\section{1-Метил-1-циклопентен} 3-Метил-1-циклопентен 1-Этил-1-циклопентен 3-Этил-1-циклопентен 1-н-Пропил-1-циклопентен 3-н-Пропил-1-циклопентен 1-Изопропил-1-циклопентен 3-Изопропил-1-циклопентен 1-н-Бутил-1-циклопентен 3-н-Бутил-1-циклопентен 1-Изобутил-1-циклопентен 1-н-Пентил-1-циклопентен 3-н-Пентил-1-циклопентен 1-Изопентил-1-циклопентен 1-н-Гексил-1-циклопентен 3-н-Гексил-1-циклопентен

\section{Циклогексен}

1-Метил-1-циклогексен 3-Метил-1-циклогексен 4-Метил-1-циклогексен 1-Этил-1-циклогексен 3-Этил-1-циклогексен 4-Этил-1-циклогексен 1-н-Пропил-1-циклогексен 3-н-Пропил-1-циклогексен 4-н-Пропил-1-циклогексен 1-Изопропил-1-циклогексен 3-Изопропил-1-циклогексен 1-Аллил-1-циклогексен 3-Аллил-1-циклогексен 1-н-Бутил-1-циклогексен 3-н-Бутил-1-циклогексен 4-н-Бутил-1-циклогексен 1-Изобутил-1-циклогексен 3-Изобутил-1-циклогексен

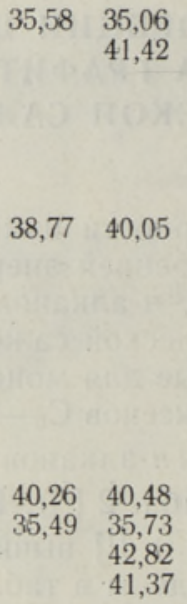

52,93
$65,48 \quad 65,48$

$37,31 \quad 36,80$

42,32

39,51

42,14

43,27

40,12

42,69

$44,76 \quad 45,47$

$45,44 \quad 44,41$

$47,26 \quad 45,94$

45,74

48,07

$47,11 \quad 48,00$ 49,78
$35,32 *$

40.99

48,27

51,18

56,57
61,99

$39,41^{* *}$

43,83

49,38

47,92

56,27

51,79

40,37

35,61

43,06

41,43

48,09

45,99

45,59

45,19

51,98

50,87

47,89

57,15

55,14

54,22

61,47

60,92

$37,06^{* *}$

42,80

39,82

42,42

45,12

44,93

46,60

49,76 .

50,74

50,94

46,64

48,98

47,56

49,90

53,74

54,47

56,20

51,85

53,05 


\begin{tabular}{l|l|l|l|l|l|l|l|l}
\hline \multicolumn{1}{c}{1} & 2 & 3 & 4 & 5 & 6 & 7 & 8 & 9 \\
\hline 1-Втор. бутил-1-циклогексен & & & & & 53,88 & 50,64 & & 52,26 \\
3-Втор. бутил-1-циклогексен & & & & & 51,75 & 52,98 & & 52,37 \\
1-н-Пентил-1-циклогексен & & & & & & 58,71 & 65,49 & 62,10 \\
3-н-Пентил-1-циклогексен & & & & & & 59,96 & 60,91 & 60,44
\end{tabular}

* Вычислены по индексам удерживания $\left[{ }^{2}\right]$.

** $-\overline{\Delta U_{1}}$, по литературным данным [3]: для метилциклопентана 31,3 , метилциклогек-

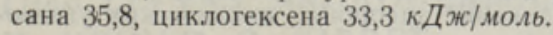

Таблица 2

углерода в молекуле значения $I, q_{s t, 1}$ и $-\overline{\Delta U}_{1}$ увеличиваются в порядке: 1-, 3- и 4-н-алкил-1-циклогексены.

Величины $-\overline{\Delta U}_{1}$ для изученных соединений могут быть рассчитаны из значений $-\overline{\Delta U}_{1}$ соответствующих $H$-алканов по следующим уравнениям:
Константы уравнения (1) для циклоалканов и циклоалкенов

\begin{tabular}{lrl}
\hline \multicolumn{1}{c|}{ Гомологический ряд } & $a_{0}$ & $a_{1}$ \\
\hline H-Алкилциклопентаны $\mathrm{C}_{6}-\mathrm{C}_{11}$ & 4,61 & 5,23 \\
H-Алкилциклогексаны $\mathrm{C}_{7}-\mathrm{C}_{12}$ & 1,67 & 5,35 \\
Изоалкилциклогексаны $\mathrm{C}_{9}-\mathrm{C}_{10}$ & 13,09 & 3,87 \\
1-н-Алкил-1-циклопентены $\mathrm{C}_{6}-\mathrm{C}_{11}$ & 13,52 & 4,33 \\
3-н-Алкил-1-циклопентены $\mathrm{C}_{6}-\mathrm{C}_{11}$ & 6,42 & 4,93 \\
1-Изоалкил-1-циклопентены $\mathrm{C}_{8}-\mathrm{C}_{10}$ & 10,40 & 4,32 \\
1-н-Алкил-1-циклогексены $\mathrm{C}_{7}-\mathrm{C}_{11}$ & 4,38 & 5,08 \\
4-н-Алкил-1-циклогексены $\mathrm{C}_{7}-\mathrm{C}_{10}$ & 10,21 & 4,57
\end{tabular}

H-алкилциклопентаны: $-\overrightarrow{\Delta U}_{1}=-\overrightarrow{\Delta U}_{1 \text { н-алкан }}-1,47+0,05 n$, н-алкилциклогексаны: $-\overline{\Delta U}_{1}=-\overline{\Delta U}_{1}$-алкан $-2,43+0,08 n$, изоалкилциклогексаны: $-\overrightarrow{\Delta U}_{1}=-\overline{\Delta U}_{1 \text { налкан }}-1,92-0,06 n$, 1-н-алкил-1-циклопентены: $-\overline{\Delta U}_{1}=-{\overline{\Delta U_{1}}}_{\text {н-алкан }}+0,75-0,19 n$, 3-н-алкил-1-циклопентены: $-{\overline{\Delta U_{1}}}=-\overline{\Delta U}_{1 \text {-алкан }}-1,19-0,02 n$, 1-изоалкил-1-циклопентены: $-\overrightarrow{\Delta U}_{1}=-\overline{\Delta U}_{1 \text { н-алкан }}-2,45+0,04 n$, 1-н-алкил-1-циклогексены: $-\overline{\Delta U}_{1}=-\overline{\Delta U}_{1}$-алкан $-0,88-0,06 n$, F 3-н-алкил-1-циклогексены: $-\overline{\Delta U}_{1}=-\overline{\Delta U}_{1 \text { н-алкан }}-1,98+0,05 n$, 4-н-алкил-1-циклогексены: $-\overline{\Delta U}_{1}=-\overline{\Delta U}_{1 \text {-алкан }}-0,27-0,11 n$.

\section{Выводы}

Рассчитаны дифференциальные мольные изменения внутренней энергии адсорбата $-\overline{\Delta U}_{1}$ для монозамещенных алкилциклопентанов, -пентенов, -гексанов и -гексенов $\mathrm{C}_{6}-\mathrm{C}_{11}$ на ГТС и рассмотрены закономерности их изменения в зависимости от числа атомов углерода в молекуле, а также структуры и положения боковой цепи.

Значения $-\overline{\Delta U}_{1}$ увеличиваются линейно с числом атомов углерода (n) в молекуле. Приведены уравнения зависимостей между $-\overrightarrow{\Delta U_{1}}$ и $n$. Разветвление боковой цепи приводит к понижению значений $-\overrightarrow{\Delta U}_{1}$ по сравнению с соответствующими углеводородами с нормальной алкильной группой у цикла. Величины $-\overrightarrow{\Delta U_{1}}$ уменьшаются по мере удаления боковой цепи от кратной связи из положения 1 в положение 3 в цикло- 
пентеновом цикле. При равном числе атомов углерода в молекуле значения $-\overrightarrow{\Delta U}_{1}$ изомерных $\boldsymbol{H}$-алкилциклогексенов увеличиваются в порядке: 1-, 3- и 4-н-алкил-1-циклогексены.

\section{Л И Т Е Р А Т У Р А}

1. М ей ст е р А., Р а н г С., Эй з е н О. Исследование адсорбции $н$-алкенов и нов на графитированной термической саже. - Изв. АН ЭССР. Хим., 1979, т. 28, № 1 , c. $15-22$.

2. Р ан г С., М ей ст е р А., Эй зе н О. Исследование адсорбции циклических углеводородов на графитированной термической саже газохроматографическим методом. - Изв. АН ЭССР. Хим. Геол., 1975, т. 24, № 3, с. 197-205.

3. Авгуль Н. Н., К и селе в А. В., Пошку с Д. П. Адсорбция газов и паров на однородных поверхностях. М., 1975, с. 369.

Институт химии

Академии наук Эстонской ССР
Поступнла в редакцию $17 / \mathrm{XI} 1978$

Aime MEISTER, Silvia RANG, O. EISEN

\section{TSUKLILISTE SUSIVESINIKE ADSORPTSIOON TERMILISELT GRAFIIDITUD TAHMAL}

Artiklis on esitatud monoasendatud tsüklopentaanide, tsüklopenteenide, tsükloheksaanide ja tsüklohekseenide $\mathrm{C}_{6}-\mathrm{C}_{11}$ adsorptsiooni diferentsiaalsete siseenergia moolmuutuste

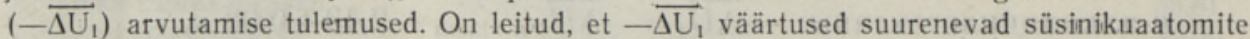
arvu suurenedes lineaarselt, ja esitatud vastavate sõltuvuste võrrandid. Võrdse süsinikuaatomite arvu puhul molekulis vähenevad isomeersete $n$-alküültsüklopenteenide $-\overrightarrow{\Delta \mathrm{U}}_{\mathrm{I}}$ väärtused külgahela nihkudes asendist 1 asendisse 3 . Isomeersete $n$-alküültsüklohekseenide $-\overline{\Delta U}_{1}$ väärtused suurenevad järjekorras 1 -, 3- ja 4-n-alküül-1-tsüklohekseen.

Aime MEISTER, Silvia RANG, O. EISEN

\section{INVESTIGATION OF ADSORPTION OF CYCLIC HYDROCARBONS ON GRAPHITIZED THERMAL CARBON BLACK}

The differential molar changes of internal energy $-\overrightarrow{\Delta U}_{1}$ at low surface coverages on graphitized thermal carbon black for mono-substituted cyclopentanes, cyclopentenes, cyclohexanes and cyclohexenes $\mathrm{C}_{6}-\mathrm{C}_{11}$ have been calculated and correlated with the molecular structure of isomers.

The $-\overline{\Delta \mathrm{U}}_{1}$ values increase linearly along with increasing the number of carbon atoms in the molecule $n$ for homologous series. The constants of equations for these straight lines are calculated. At equal $n$ the $-\overrightarrow{\Delta \mathrm{U}_{1}}$ values decrease with the shift of the side chain from the position 1 to the position 3 in $n$-alkylcyclopentene series; for $n$-alkylcyclohexenes they increase in the following order: 1-, 3-, 4-n-alkyl-1-cyclohexenes. 